\title{
Implikasi Hukum Kewarisan terhadap Ahli Waris Yang Lahir Dari Perkawinan Berbeda Agama
}

\author{
Winda Fitri* \\ Fakultas Hukum Universitas Internasional Batam \\ *Correspondance email: winda@uib.ac.id
}

\begin{abstract}
Abstrak. Hukum kewarisan Indonesia sampai saat ini masih dalam keadaan pluralisme terdiri dari hukum kewarisan barat dalam KUH Perdata, hukum kewarisan adat dan hukum kewarisan Islam. Kemajemukan ini akan berimplikasi ke berbagai hal. Diantaranya, perberbedaan agama dipandang menjadi faktor penghalang seorang anak mendapatkan hak kewarisan dari orangtuanya. Dalam Hukum Islam, anak yang lahir dari orang tua yang berbeda agama dengan orang tuanya akan terhalang untuk mendapatkan harta kewarisanan, permasalahnya ini tidaklah sejalan dengan hukum perdata dan hukum adat yang tidak menjadikan hal ini sebagai penghalang anak menerima kewarisanan. Penelitian ini dibuat dengan tujuan untuk menganalisis implikasi hukum dari pelaksanaan perkawinan berbeda agama terhadap ahli waris dan bagaimana perlindungan hukum terhadap hak ahli waris yang lahir dari perkawinan berbeda agama. Penelitian ini menggunakan jenis penelitian hukum yuridis-normatif dengan melakukan penelaahan dan interpretasi terhadap hal teoritis yang menyangkut konsep hukum. Penyelesaian perihal hak kewarisan anak yang lahir dari perberbedaan agama para pihak yang tunduk pada hukumnya yang berbeda berdasarkan hukum agama atau hukum adat. Terdapatnya persamaan dan perberbedaan implikasi dari ketentuan Pasal 832 KUHPerdata dan Pasal 171 KHI. Namun perlindungan bagi anak lahir dari berbeda agama dapat memperoleh harta dari orangtuanya melalui Hibah, Wasiat dan hadiah dengan prinsip keadilan.
\end{abstract}

Kata kunci: Hukum Waris, Perkawinan, berbeda Agama.

Abstract. Law of inheritance in Indonesia up to now in a plurality, consisting of Islamic inheritance law, western inheritance law in the Civil Code and customary inheritance law. The plurality will have implications for various things. Religious differences are seen to be a factor preventing a child from obtaining inheritance rights from parents. In Islamic law, children from different religions and their parents will prevent from receiving inheritance, not in line with civil law that one barrier to receiving inheritance is religious different. This study analyzing the legal implications of the implementation of interfaith marriage for the heirs and how the legal protection of the rights of heirs born from interfaith marriages. The research methodology that the uses is normative by conducting analysis. The settlement of the issue children born from different religions of each party is subject to different laws based on religious law or customary law. There are similarities and differences in the implications of the provisions of Article 832 of the Civil Code and Article 171 of the Compilation of Islamic Law. However, protection for children born of different religions can obtain asset from their parents through grants, wills and gifts with the principle of justice.

Keywords: Inheritance Law, Marriage, Different Religions.

\section{PENDAHULUAN}

Dalam hal mengaktualkan suatu cita hukum berbangsa dan bernegara Indonesia pada orientasi nilai-nilai Ketuhanan, Kemanusiaan dan Kemasyarakatan maka suatu perkawinan hendaklah mengacu pada Pancasila yang kemudian nilai tersebut dituangkan dalam Undang-Undang Dasar Tahun $1945 .^{1}$

Perkawinan menurut hukum nasional Indonesia sudah dilegalisir semenjak tahun 1974 yaitu dengan disahkannya Undang-Undang Nomor 1 Tahun 1974 tentang Perkawinan dan saat ini sudah disahkan perubahan pertama pada UU perkawinan yaitu Undang-Undang Nomor 16 Tahun 2019 tentang Perubahan Atas Undang-Undang Nomor 1 Tahun 1974 tentang Perkawinan (selanjutnya disebut UU Perkawinan).

Dimana secara tegas dinyatakan dalam UU Perkawinan bahwasanya perkawinan merupakan ikatan lahir-batin antar seorang laki-laki dengan seorang perempuan dengan tujuan membina rumah tangga yang kekal serta bahagia berdasarkan Ketuhanan Yang Maha esa. Sedangkan berdasarkan perspektif Hukum Islam, perkawinan ialah sunnatullah penciptaan manusia yang saling berpasangan antara perempuan dan laki-laki. ${ }^{2}$

Setiap WNI berhak mendapatkan perlindungan oleh negara berupa pemenuhan fasilitas secara merata. ${ }^{3}$ Indonesia adalah negara yang berlandaskan pada Pancasila, dimana Sila yang pertamanya ialah "Ketuhanan Yang Maha Esa", seyogyanya perkawinan memiliki kaitan yang sangat erat dengan agama, maka dari itu perkawinan tidak

\footnotetext{
${ }^{1}$ Kadek Wiwik Indrayanti, "Penetapan Dan Pencatatan Perkawinan Berbeda Agama di Indonesia Yang Berkeadilan Dan Berkemanusian", Jurnal Cakrawala Hukum Vol. 7, No. 2 (Desember 2016): 196.

${ }^{2}$ Umar Hari Sanjaya dk, Hukum Perkawinan Islam di Indonesia, (Yogyakarta: Gama Media, 2017), hlm. 12.

${ }^{3}$ Rokilah, "Implikasi Kewarganegaraan Ganda bagi Warganegara Indonesia”, Jurnal Ilmu Hukum "Ajudikasi” Vol. 1, No. 2, (Desember 2017): 132.
} 
hanya memiliki unsur lahiria, tetapi unsur batinia juga memiliki banyak peran penting untuk membina rumah yang kekal berdasarkan keyakinan menurut agama dan kepercayaannya. Sehingga Perkawinan dan agama memiliki ikatan yang erat dan tak terpisahkan. Menurut Masykuri Abdillah, Hukum Islam di Indonesia memiliki dua bagian; pertama, Hukum Islam dalam bentuk hukum formil yang dilegalisasikan menjadi hukum positif untuk umat muslim di Indonesia; kedua, Hukum Islam sebagai hukum normatif yang diimplementasi secara nyata oleh umat Muslim. ${ }^{4}$

UU Perkawinan Ps. 1 (2) mempertegas bahwa perkawinan adalah sah jika perkawinan itu dilaksanakan menurut hukum dari agama dan kepercayaan masing-masing. Hampir seluruh agama di Indonesia mengatur hukum tentang perkawinan, yang pada umumnya berharap perkawinan antara pria dan wanita yang sama agama. Hal tersebut dikarenakan agama adalah dasar yang paling utama dan sangatlah penting untuk penentuan keberhasilan suatu keluarga.

Dalam UU Ps.56 Perkawinan memperbolehkan perkawinan campuran antar dua individu yang menundukkan diri pada dua sistem hukum yang berbeda. Aturan ini mengatur perberbedaan warga negara dan namun tidak menegaskan bahwa diperbolehkan perkawinan berbeda agama.

UU Perkawinan mempertegas bahwa suatu perkawinan ialah sah apabila dilakukan menurut hukum tiap agama dan kepercayaan masing-masing itu. Dari ketentuan Ps. 2 UU Perkawinan belum dimungkinkan dapat dilakukannya perkawinan berbeda agama antara calon pengantin perempuan dan calon pengantin laki-laki. Dikarenakan bagi umat muslim yang beragama Islam tidaklah sah melakukan perkawinan tidak berdasarkan ketentuan prinsip syariat Islam, begitu pula dengan umat beragama Kristen juga tidaklah sah jikalau dilakukan tidak sesuai dengan ketentuan agama Kristen, dalam agama Buddha adanya upacara yang dipimpin oleh Pandita serta pelaksanaan ritual pemberkatan lainnya. ${ }^{5}$

Perkawinan berbeda agama yang tidak sah akan membawakan konsekuensi hukum yang tidak sah untuk segala implikasi yang ditimbulkan dari perkawinan itu. Ditegaskan kembali dalam Ps.43 (1) UU Perkawinan menyatakan bahwa "Anak yang dilahirkan di luar perkawinan hanya memiliki hubungan perdata dengan ibunya, keluarga ibunya". Maka dari itu, perkawinan yang terjadi antara pasangan yang akan menikah hendaklah merupakan agama yang sama, karena akan sulit bagi tiap-tiap agama untuk melegalisir perkawinan berbeda agama kecuali salah satu pasangan akhirnya menundukkan diri untuk mengikuti agama pasangannya itu. Kemudian, dinyatakan dengan tegas bahwa perkawinan berbeda agama tidak diinginkan berdasarkan pandangan hukum positif Indonesia, karena tidak sesuai dengan ketentuan yang berlaku di sistem hukum Indonesia. ${ }^{6}$

Pada dasarnya ketentuan di negara Indonesia tidak diatur secara tegas adanya peraturan terkhusus mengenai perkawinan antara pasangan berbeda agama. ${ }^{7}$ Sehingga secara praktiknya, seringkali calon mempelai perempuan dan calon mempelai laki-laki berbeda agama yang akan menikah terlebih dahulu memohon penetapan oleh Pengadilan. Perkawinan yang sah menurut UU Perkawinan hendaklah memenuhi syarat menurut agama dan kepercayaannya masing-masing serta menurut aspek administratif perkawinan. Perkawinan yang sudah dilaksanakan berdasarkan hukum agama serta kepercayaan haruslah dicatatkan oleh petugas pencatatan nikah dengan tujuan untuk terciptanya tertib administrasi kependudukan (selanjutnya disebut Adminduk). Dengan terciptanya tertib adminduk akan menghindari ketidakjelasan administrasi yang berhubungan erat dengan kepastian hukum seseorang warga negara. ${ }^{8}$

Fenomena pekawinan berbeda agama bukanlah menjadi suatu hal yang baru dan rahasia umum di Indonesia karena masih banyaknya pada praktiknya pasangan berbeda agama melangsungkan perkawinan berbeda agama dan sampai adanya penetapan pengadilan. Hal ini terjadi di Minahasa Utara, Provinsi Sulawesi Utara, dimana Pengadilan Negeri Airmadidi sudah menetapkan putusan No 41/PDT.P/2012/PN.AMD. Putusan tersebut menegaskan terkait diizinkannya dilangsungkan perkawinan berbeda agama antara Dani S. dan Astriani V.B di depan pegawai Capil Airmadidi. Berdasarkan hal tersebut timbulnya ketidakpastian hukum di Indonesia jika dikaitkan dengan kepercayaan tiap-tiap agama dimana semua agama yang diakui di Indonesia tidak memperbolehkan dilangsungkan perkawinan yang dilakukan jika kedua calon mempelai berbeda agama. ${ }^{9}$

\footnotetext{
${ }^{4}$ Fitria Agustin, "Kedudukan Anak dari Perkawinan Berbeda Agama Menurut Hukum Perkawinan Indonesia”, Ajudikasi Jurnal Ilmu Hukum Vol. 2, No. 1, (Juni 2018): 44.

5 Akhmad Munawar, "Sahnya Perkawinan menurut Hukum Positif yang berlaku di Indonesia", Al' Adl-Jurnal Hukum Vol. 7, No. 13, (Juni 2015): 24.

${ }^{6}$ Lu Sudirman dan Jendy Herlinda Karwur, "Perlindungan Hukum bagi Pasangan yang Melakukan Perkawinan Berbeda Agama di Indonesia”, Journal of Judicial Review Vol. 16, No. 2, (Desember 2014): 53.

7 Dewi Septiandani, Dian; Triasih, Dharu dan Tuti Muryati, "Kontruksi Hukum Perkawinan Berbeda Agama Dalam Perspektif Hukum Islam Dan Hukum Positif Indonesia”, Humani Vol.7, No.1, (Januari 2017): 47.

${ }^{8}$ Nurhasan dan Fitri Yani, “Akibat Hukum Perkawinan di Bawah Tangan terhadap Istri, Anak, dan Harta Kekayaan dalam Perspektif Hukum Islam dan Undang-Undang Nomor 1 Tahun 1974 Tentang Perkawinan”, Jurnal Wajah Hukum Vol.3, No.2, (Oktober 2019): 158

9 Anggreini Carolina Palandi, “Analisa Yuridis Perkawinan Berbeda Agama di Indonesia”, Lex Privatum Vol. 1, No. 2, (Juni 2013): 197
} 
Kalangan artis Indonesia sebagai public figure tanah air juga ada yang melangsungkan perkawinan berbeda agama. Pasangan artis fenomenal yang menikah berbeda agama di Indonesia yaitu artis Deddy Corbuzier (beragama Katolik) dengan Kalina (Agama Islam), pada tahun 2005 lalu perkawinan dilaksanakan di Kantor Urusan Agama. Kemudian artis bernama Jamal Mirdad (Agama Islam) dan Lidya Kandou (Agama Kristen) yang menikah di Indonesia namun permohonan perkawinan mereka diterima oleh pihak Pengadilan Negeri yang sebelumnya sempat ditolak oleh KUA dan KaCapil. ${ }^{10}$

Perkawinan yang berlangsung dari pasangan yang berbeda agama sering sekali selanjutnya akan berimplikasi kepada hak seorang anak yang lahir dari perkawinan berbeda agama yaitu salah satunya hak mendapatkan kewarisan dari orang tua kandungnya.

Hukum kewarisan di Nusantara ini sendiri hingga saat ini masih dalam kondisi pluralistik, sehingga membuat masyarakat bingung dalam menerapkan sistem hukum mana yang berkeadilan. Di Indonesia masih berlaku banyaknya sistem hukum kewarisan, yakni hukum kewarisan adat, hukum kewarisan Islam dan hukum kewarisan Barat yang tercantum dalam Kitab Undang-Undang Hukum Perdata. Pluralistik ini akan menjadi makin berkembang dikarenakan hukum kewarisan adat yang ada saat ini nyatanya tidak bersifat tunggal, namun juga keanekaragaman akan mengikuti bentuk-bentuk masyarakat adat serta system kekeluargan masyarakat Indonesia. ${ }^{11}$

Pada kenyataannya ketiga hukum kewarisan ini sama dimana sama-sama menjelaskan tentang peralihan hak atas harta benda pewaris kepada ahli waris. Walaupun dalam prakteknya terjadi perberbedaan karena hukum Islam dan hukum kewarisan barat (BW). Ditinjau dari sisi yang berbeda bahwa dengan adanya budaya unifikasi, hukum adat masih melekat dan memiliki ikatan yang kuat di dalam masyarakat. ${ }^{12}$ Dan luar biasanya di beberapa wilayah di Indonesia hukum Islam telah hidup dan berkembang sehingga menjadikan rujukan dari hukum adat itu sendiri. Maka dari itu sampai saat ini walaupun adanya unifikasi hukum perkawinan (pasca munculnya UU Perkawinan) pada prinsipnya masih banyaknya masyarakat yang memakai hukum perkawinan adat dibeberapa wilayah. ${ }^{13}$

Dengan adanya kemajemukan tersebut dalam praktiknya kerukunan sering terganggu dengan permasalahan pembagian harta waris, dengan berbeda agama di dalam perkawinan telah menjadi penghalang hak seorang anak mendapat kewarisan. Sehingga dalam persoalan perkawinan berbeda agama, sering menjadi persoalan hukum yang terjadi di Indonesia terhadap bagaimana pelaksanaan dan prosedur serta peryaratan dan akibat hukum yang mungkin muncul setelahnya. Ketentuan terkait perkawinan berbeda agama di Indonesia jika ditinjau dari agama mayoritas di Indonesia yaitu Agama Islam yang ketentuannya merujuk pada KHI, terdapat ketentuan mengenai syarat dan rukun kelangsungan perkawinan umat Islam.

Sehingga jika ditinjau dari beberapa peristiwa mengenai pelaksanaan perkawinan berbeda agama di Indonesia, dengan berlandaskan pada ketentuan mengenai Perkawinan di Indonesia, peneliti akan meneliti secara mendalam terkait Ahli waris yang lahir dari perkawinan berbeda agama berdasarkan aspek hukum nasional dan Hukum Agam yang dirangkum dalam penelitian yang berjudul: "Implikasi Hukum Kewarisan terhadap Ahli waris yang Lahir dari Perkawinan Berbeda Agama di Indonesia".

\section{METODE}

Tipe penelitian yang akan dikaji oleh Penulis pada objek penelitian ini adalah penelitian hukum normatif. Penelitian ini termasuk tipe penelitian hukum yang bersifat deskriptif preskriptif yang bertujuan mencari problem solution dengan melakukan penelaahan dan interpretasi terhadap hal teoritis yang menyangkut konsep, teori, asas dan norma hukum yang berkaitan dengan peraturan peraturan perundang-undangan. ${ }^{14}$ Dalam metode penelitian ini memakai pendekatan peraturan undang-undang, pendekatan konseptual dan operasional.

Dalam penelitian hukum normatif pada penelitian ini, maka jenis data yang akan diolah oleh Penulis berdasarkan pada data sekunder yang terdiri dari: Bahan hukum primer, merupakan bahan-bahan hukum terhadap peraturan perundang-undangan tentang perkawinan di Indonesia. Adapun penelitian terhadap bahan hukum primer yang akan ditinjau oleh Penulis yaitu: UUD Tahun 1945; UU Perkawinan; KUHPerdata; dan KHI di Indonesia.

Metode pengumpulan data dengan mengadakan studi penelaahan terhadap literatur peraturan undang-undang, buku, artikel ilmiah, pendapat ahli hukum, dan berbagai hasil penelitian lainnya yang berhubungan dengan penelitian ini. Pendekatan yang dilakukan dalam mengimplementasikan data sekunder dengan memakai metode deduktif dimana penelitian ini mencoba mencari solusi dari isu hukum yang terjadi. Pada penelitian ini, Penulis akan menggunakan metode analisis data yang tidak mempergunakan hitungan yaitu metode kualitatif yaitu penelitian yang mendapatkan data dalam bentuk deskriptif berupa suatu tulisan atau ucapan dan juga sikap perbuatan hukum dari orang yang

10 Ibid

${ }^{11}$ Adelina Nasution, "Pluralisme Hukum Kewarisan Di Indonesia”, Jurnal Al-Qadhâ Vol. 5, No. 1, (Juli 2018 ): 20.

12 M.Misbahul Mujib, "Memahami Pluralisme Hukum di Tengah Tradisi Unifikasi Hukum: Studi atas Mekanisme Perceraian Adat”, Jurnal Supremasi Hukum Vol. 3, No. 1, (Juni 2014): 20.

13 ibid

${ }^{14}$ Soerjono Soekanto, Pengantar Penelitian Hukum, (Jakarta: UI Press, 2008), hlm. 50-51. 
diamati. ${ }^{15}$ Penelitian kualitatif berhubungan dengan ide, persepsi, pendapat, atau kepercayaan orang yang diteliti, kesemuanya tidak dapat diukur dengan angka. ${ }^{16}$

\section{HASIL DAN PEMBAHASAN}

\section{Implikasi hukum dari pelaksanaan perkawinan berbeda agama terhadap anak sebagai ahli waris}

Fenomena perkawinan berbeda agama yang terjadi di Indonesia bukanlah rahasia umum, banyak kalangan yang masih melaksanakan perkawinan berbeda agama. Hal inilah tentunya menjadi alasan perlu adanya hukum yang mengatur pelaksanaan perkawinan berbeda agama tersebut. Aturan mengenai pelaksanaan perkawinan secara sah jelas diatur pada ketentuan UU Perkawinan, terutama dalam Pasal 2 ayat 1 mengenai syarat sah suatu perkawinan. Namun UU Perkawinan tidak mempertegas secara jelas terkait perkawinan berbeda agama.

Maka dari itu perkawinan berbeda agama ditafsirkan lain kemudian berdasar agama yang dianut masing-masing individu. Misalnya pada Agama Islam melarang wanita yang melaksanakan perkawinan dengan pria bukan memeluk agama Islam, hal ini mengacu pada Sumber Hukum Islam utama yaitu Al'Quran QS. al-Baqarah Ayat 221 dan ditegaskan dalam Fatwa Majelis Ulama Indonesia (MUI) pada 1426 H/2005 M, kemudian dalam Agama Kristen larangan untuk menikah berbeda agama bersumber pada I Korintus 6: 14-18.

Berlangsungnya perkawinan berbeda agama dilarang oleh beberapa hukum agama dikarenakan akan timbulnya implikasi hukum yang besar terhadap status anak selanjutnya yang lahir dari perkawinan berbeda agama. Keabsahan hukum seorang anak yang lahir dari perkawinan berbeda agama, bisa berlandaskan berdasarkan Pasal 42 dan Pasal 43 UU Perkawinan, yang menegaskan bahwa "anak sah adalah anak yang lahir dari perkawinan yang sah, dan terhadap anak yang lahir di luar perkawinan hanya memiliki hubungan keperdataan dengan ibu beserta keluarga dari ibunya".

Sehingga jika anak yang lahir dari perkawinan yang sah, baik melalui Kantor Urusan Agama ataupun Kantor Catatan Sipil, maka kedudukan hukum anak tersebut adalah sah menurut hukum, namun apabila anak yang dilahirkan dari perkawinan berbeda agama, dan setelahnya tetap berpegang teguh pada agamanya, maka anak dari perkawinannya berhak untuk menentukan pilihan agama yang akan dianutnya dan beribadat menurut agama dan kepercayaannya, bila waktunya anak telah siap bertanggungjawab dan berakal, sesuai dengan Pasal 42 UU Nomor 23 Tahun 2002 Tentang Perlindungan Anak, hal tersebut biasanya dapat dicapai apabila anak sudah mendekati usia 18 (delapan belas) tahun.

Implikasi selanjutnya yaitu terhadap Hak Kewarisan anak yang harus dipertimbangkan dari sekarang untuk kelanjutan hidup anak jika salah satu orangtuanya sudah meninggal atau dalam hal ini bisa disebut bahwa salah satu orang tua jika berubah statusnya menjadi seorang pewaris yang akan mewariskan harta benda peninggalannya kepada ahli waris anaknya. Dalam hal ini seorang anak sebagai ahli waris tidak memungkinkan untuk beragama lebih dari satu dikarenakan agama adalah persoalan keyakinan, implikasinya seorang anak akan hanya seagama dengan salah satu dari agama orangtuanya dana tau dapat juga menganut agama lain selain yang dianut oleh kedua orangtuanya.

Apabila terhadap perkawinan pasangan yang melahirkan dua orang anak, yang mana salahsatunya beragama sesuai dengan orangtuanya maka anak tersebut akan memperoleh kewarisanan dari orangtuanya, namun jika salah satu anak lainnya menganut agama sesuai keyakinannya sendiri diluar agama sesuai orangtuanya, maka anak tersebut tidak mendapatkan kewarisanan dari orangtuanya tersebut. Hal inilah yang disebabkan karena perberbedaan agama tersebut akan berimplikasi terhadap gugurnya hak mewaris seorang anak. Oleh karenanya, pembagian kewarisan antara kedua anak yang berbeda agama tersebut akan menimbulkan suatu ketidakadilan.

Perkawinan berbeda agama berdasarkan sudut pandang hukum agama merupakan perkawinan yang tidak sah, oleh karenanya anak yang lahir dari perkawinan berbeda agama hanya memiliki hubungan keperdataan dengan ibunya, yang mana hal tersebut menjadi disamakan terhadap anak luar perkawinan. Apabila anak lahir luar perkawinan itu diakui oleh ayahnya, maka anak yang dimaksud dapat memperoleh kewarisanan. Namun pada fenomena yang terjadi mengenai perkawinan berbeda agama, anak yang lahir dari perkawinan tersebut dapat menjadi ahli waris sah, yang dapat mewarisi dari ibunya akan tetapi tidak berhak mewaris terhadap ayahnya, sepanjang tidak ada pihak ketiga yang mengajukan kepada Pengadilan untuk membuktikan perkawinan tersebut merupakan perkawinan tidak sah. ${ }^{17}$

Hukum kewarisan di Indonesia sendiri hingga saat ini masih dalam keadaan pluralistik (majemuk), sehingga membuat masyarakat bingung dalam menerapkan sistem hukum mana yang berkeadilan. Di Indonesia masih berlaku pluralistik sistem hukum kewarisan, yaitu hukum kewarisan adat, hukum kewarisan Islam dan hukum kewarisan Barat yang tercantum dalam KUHPerdata.

15 Pupu Saeful Rahmat, "Penelitian Kualitatif”, Journal Equilibrium Vol. 5, No. 9, (Juni 2009): 2.

16 Sulistyo Basuki, Metode Penelitian, (Jakarta: Wedatama Widya Sastra dan Fakultas Ilmu Pengetahuan Budaya Universitas Indonesia, 2006), hlm. 78.

${ }^{17}$ Oktavia Milayani, "Kedudukan Hukum Ahli waris Yang Mewaris Dengan Cara Mengganti Atau Ahli waris", Al'Adl Vol. 9, No. 3, (Desember 2017): 406. 
Hukum kewarisan barat atau hukum kewarisan BW yang berdasarkan sistem individual, yang mana peninggalan pewaris yang telah meninggal dilakukan pembagian kepada perorangan ahli waris. Aturan ini diberlakukan kepada WNI berketurunan asing yaitu eropa, china, arab dan lain-lainnya yang tidak lagi menjadikan agama sebagai ketentuan pokok. Hingga saat ini, ketentuan terkait hukum kewarisan barat masih bertahan hingga saat ini, walau ada bebeerapa ketentuan yang ada di isi KUHPerdata sudah dinyatakan tidak berlaku, yaitu hukum perkawinan menurut BW sudah dicabut dikarenakan sudah berlakunya UU Perkawinan, terkait perkawinan yang secara unifikasi diberlakukan untuk semua WNI.

Seperti yang sudah penulis paparkan diatas bahwa perkawinan berbeda agama adalah perkawinan yang tidak sah karena tidaklah diakui oleh hukum, sehingga kedudukan anak yang lahir dari perkawinan berbeda agama merupakan anak tidak sah pula maka dari itu bisa diartikan sebagai anak yang lahir dari luar nikah, maka anak tersebut hanya memiliki ikatan keperdataan dengan ibunya maka dari itu hanya berhak mendapatkan harta dari ibunya. Tetapi anak lahir dari luar nikah tetaplah dapat mewaris apabila ayah biologisnya mengakuinya. Hak kewarisan aktif seorang anak yang lahir dari luar nikah yang sah ditegaskan didalam Ps. 862 hingga Ps. 866 dan Ps. 873 ayat (1) KUHPerdata.

Status anak lahir dari luar nikah yang sah diakui pada dasarnya dapat disamakan dengan kedudukan ahli-waris lainnya. Maka dari itu anak yang lahir luar pernikahan yang sah (perkawinan berbeda agama) diakui pula memiliki hak yang dimiliki seorang ahli waris, perihal yang memberbedakannya hanya dibagian yang dia terima belum sama dengan anak sah. Jumlah pembagian kewarisanan dari anak lahir dari perkawinan berbeda agama tergantunglah dari derajat hubungan kekerabatan dari ahli waris yang sah tersebut.

Berkaitan dengan ahli waris, berdasarkan ketentuan Ps. 832 KUHPerdata menyatakan bahwa "Menurut undangundang yang berhak menjadi ahli waris ialah para keluarga sedarah, baik yang sah menurut undang-undang maupun yang diluar perkawinan, dari suami atau isteri yang hidup terlama menurut peraturan-peraturan berikut ini". Sehingga dapat disimpulkan dari asas dalam Ps. 832 KUHPerdata bahwa berdasarkan undang-undang, untuk bisa mewaris seseorang wajib memiliki ikatan darah dengan pewarisnya. Hubungan darah tersebut ialah bisa sah atau luar kawin dengan artian berbeda agama pun bisa, baik melalui garis seorang peremupuan ataupun dari garis laki-lakinya.

Pernyataan diatas sangat berbeda halnya dengan pengaturan berdasarkan hukum kewarisan Islam, bahwa perkawinan berbeda agama sangat dilarang atau haram hukumnya. Dimana yang dijadikan dasar hak untuk mewarisi menurut sumber hukum utama Hukum Islam yaitu Al-Qur'an yaitu karena ikatan darah, karena ikatan semenda atau perkawinan yang sah, serta karena hubungan persaudaraan.

Merujuk pada Pasal 171 Huruf c juncto Pasal 172 Kompilasi Hukum Islam, bahwasanya seorang dapat menjadi ahli waris, yaitu "orang yang memiliki hubungan darah dengan pewaris, yang memeluk agama Islam ditentukan berdasarkan kartu identitas ataupun dari sebuah kesaksian/pengakuan, serta yang tidak dihalangi menurut hukum untuk menjadi ahli waris". Dengan artian berdasarkan dalam hukum kewarisan Islam, ahli waris yang tidak seagama dengan pewaris, bukan merupakan ahli waris dari pewaris yang beragama Islam dan mereka tidak saling mewaris.

Oleh karena itu, anak yang lahir dari perkawinan berbeda agama, tidaklah bisa mewaris bila anak tidak seagama dengan pewaris yang beragama Islam. Namun apabila ahli waris berasal dari agama non muslim maka dapat memperoleh warisan dari pewaris non muslim. Antara pewaris dan ahli waris harus memiliki hubungan darah dan beragama Islam maka ia dapat saling mewarisi, hal ini ditegaskan dalam Pasal 171 Huruf c Kompilasi Hukum Islam.

Pernyataan-pernyataan diatas pun berbeda halnya juga dengan pengaturan pada hukum waris adat di Indonesia tidaklah terlepas dari pengaruh budaya masyarakat dari sistem kerabatnya yang berbeda, dan pembagiannya pun bukan jumlah pecahan seperti pembagian kewarisan hukum Islam. Hukum kewarisan adat memiliki corak sendiri dari hukum kewarisan lainnya. Perkembangan hukum Islam ataupun hukum barat tentulah ikut berpengaruh pada kewarisan adat, perihal ini tentunya juga akan mempengaruhi masyarakat adat di Indonesia.

Sistem kewarisan adat di Indonesia dipengaruhi oleh dasar garis kekerabatan. Ada tiga dasar pokok garis kekerabatan atau keturunan, yaitu: pertama; Patrilineal dimana tiap individu selalu mengkaitkan dirinya dari garis kekerabatan ayah, kedua: Matrilineal, dimana setiap individu mengkaitkan dirinya dari kekerabatan ibu, ketiga: Parental atau Bilateral, dimana setiap individu mengkaitkan dirinya dengan kekerabatan keturunan dari ibu nya ataupun dari ayah nya. ${ }^{18}$

Dalam hukum Adat pada dasarnya pembagian kewarisan kepada anak yang lahir dari perkawinan beda agama bukanlah problem dikarenakan belum menjadikan hijab mewaris. Pada saat hukum Adat diimplementasikan maka tidak diperoleh kepastian hukum dikarenakan tiap adat di Indonesia berbeda-berbeda penerapan ketentuanya, oleh karena itu akan terjadilah banyak hukum yang berbeda. Dan apabila dilimplementasikan hukum Adat dalam pembagian kewarisanan maka akan ada dua perihal yang akan tidak terciptanya keadilan serta dapat menimbulkan kerugian kepada salah satu pihak yaitu, pertama; masyarakat patrilinial dimana masyarakat suku Batak pada dasarnya membagikan harta waris lebih diperbanyak kepada anak laki-laki. Kedua; masyarakat matrilineal dimana masyarakat suku Minang pada pada dasarnya membagikan harta waris lebih diperbanyak kepada anak perempuan.

${ }^{18}$ Adelina Nasution, "Pluralisme Hukum Waris Di Indonesia”, Jurnal Al-Qadhâ, Vol. 5, No. 1, (2018): 24. 
Namun pada prakteknya fenomena terkait hak kewarisan terhadap anak lahir dari pasangan berbeda agama dapat disesuaikan lagi bagi para pihak yang bersangketa untuk dapat memilih menundukkan diri pada salah satu aturan hukum, apakah Hukum Agama atau Hukum Nasional Perdata serta Hukum Adat mengenai kewarisan. Dikarenakan masih adanya peraturan hukum mengenai hukum kewarisan yang majemuk, yang dapat menimbulkan halangan pada penentuan hak kewarisan terhadap anak yang lahir dari pasangan yang berbeda agama.

Pada dasarnya setiap individu akan menemukan keadilan di pengadilan yang difasilitasi oleh negara. Untuk keluarga bukan muslim ataupun untuk keluarga Muslim yang tidak menginginkan memakai hukum kewarisan Islam, maka mereka akan merujuk pada hukum kewarisan Barat atau hukum positif yang bersumber dari KUH Perdata. Bagi individu yang berlandaskan pada hukum adat mereka bisa merujuk pada Hukum Kewarisan Adat, sedangkan individu beragama Islam yang memakai Hukum Kewarisan Islam yang berlandaskan pada KHI. Hukum apapun yang akan dijadikan rujukan perihal yang paling dipentingkan adalah tetap mengedepankan rasa keadilan dan musyawarah. Maka dari itu keperluan terhadap hukum kewarisan yang jelas, terperinci, dan pasti serta sesuai dengan tata kehidupan masyarakat Indonesia yang berbeda-beda semakinlah terasa mendesak.

\section{Perlindungan Hukum Terhadap Hak Ahli waris yang Lahir dari Perkawinan Berbeda Agama.}

Setiap WNI dijamin haknya oleh UUD NRI 1945 untuk membentuk keluarga dan melangsungkan sebuah pernikahan. Oleh karenanya, dalam pelaksanaan kehidupan sehari-hari masyarakat berhak untuk melakukan perbuatan maupun yang termasuk perbuatan hukum sesuai agama dan kepercayaannya masing-masing. Hal ini termasuk hak masyarakat untuk menikah dengan pasangan mereka, dengan pelaksanaan perkawinan yang telah ditentukan menurut hukum dan agama mereka.

Walaupun berdasarkan hukum kewarisan Islam, anak yang lahir dari perkawinan beda agama tidak mendapatkan bagian waris dari orang tua yang berbeda agama dengannya, tetapi ia tetap dapat memperoleh haknya melalui hibah, wasiat dan hadiah dari orang tua yang berbeda agama tersebut. Hal ini sudah dipertegaskan dan diamanatkan dalam Ps. 209 KHI.

Berdasarkan hal-hal yang sudah penulis paparkan pada pembahasan pertama bahwa masih adanya pluralisme (kemajemukan) hukum kewarisan yang berlaku di Indonesia, maka hal ini akan menjadi penghambat/penghalang dalam hak mewaris anak yang lahir dari perkawinan berbeda agama. Jika ada yang bertanya peraturan hukum manakah yang berlaku, hal ini kembali kepada tiap-tiap pihak (pewaris maupun ahli waris) tentulah wajib berpegang teguh kepada peraturan hukum manakah mereka tunduk terkhusus agama yang dianutnya.

Sedangkan Berdasarkan pada teori perlindungan hukum menurut ahli hukum Hetty Hasanah, S.H., M.H yaitu perlindungan hukum merupakan "upaya dalam menjamin adanya kepastian hukum, untuk memberikan perlindungan hukum kepada pihak yang melakukan tindakan hukum". Perihal ini ditujukan untuk melindungi hak asasi masyarakat negara Indonesia dalam melaksanakan suatu perilaku hukum. Seseorang yang melakukan perbuatan hukum pastinya menjadikan peraturan undang-undang yang diberlakukan dijadikan sebagai acuan, dalam melaksanakan perbuatannya tersebut. Dalam peraturan undang-undang yang berlaku tersebut, dimana diatur oleh negara terhadap jaminan kepastian hukum yang berhak diperoleh oleh rakyat.

Perbuatan hukum ini berkaitan dengan perkawinan yang hendak dilangsungkan oleh individu satu dengan individu lainnya, yang perlu memperhatikan prosedur maupun syarat-syarat dan ketentuan aturan yang telah ditegaskan oleh Peraturan Per-UU. Namun pada umumnya, diketahui secara jelas bahwa peraturan mengenai perkawinan pasti diatur pada UU Perkawinan yang dalam hal ini berdasarkan UU Perkawinan, namun ketentuan mengenai perkawinan berbeda agama masih belum ditentukan secara pasti maupun secara tegas pada peraturan undang-undang mengenai perkawinan di negara Indonesia.

Dalam UU No. 23 Tahun 2002 tentang Perlindungan Anak juga tidak membahas terkait Hak seorang anak yaitu memperoleh hak kewarisan, hanya memperjelas terkait hak untuk hidup, melangsungkan kehidupan, dan perkembangan terhadap anak. Maka dari itu, jaminan kepastian hukum terhadap para pihak yang diakibatkan dari adanya perkawinan secara berbeda agama pada dasarnya belum dapat diperoleh secara merata dan tegas, dikarenakan beberapa putusan mengenai permohonan perkawinan berbeda agama ini masih terjadi penolakan, kemudian terhadap pencatatan perkawinan berbeda agama pun tidak dapat disetujui oleh pejabat yang berwenang karena keterbatasan maupun kemajemukan aturan hukum mengenai perkawinan berbeda agama dan Hak Kewarisan.

Pada dasarnya, apabila pewarisan ditinjau menurut aspek sebuah keadilan, kemudian diketahui adanya larangan mengenai perkawinan berbeda agama, maka hal itu akan memberikan perlindungan bagi hak kewarisan seseorang. Adapun latar belakang maksud tersebut dikarenakan hak kewarisan seorang anak akan ditentukan dari orangtua mereka, dengan ketentuan apakah anak tersebut akan menganut agama menurut turunan dari orangtuanya, ataukah anak tersebut akan memilih agama dan keyakinannya sendiri. Karena pada umumnya, menganut agama ialah keyakinan yang dijamin negara kepada individu untuk memeluk dan beribadat menurut kepercayaannya masingmasing. 


\section{SIMPULAN}

1.

Pluralisme hukum perkawinan

Indonesia berimplikasi pada ketidakpastian status anak sebagai ahli waris dari orang tua yang berbeda agama dengannya, dalam hukum kewarisan Islam ditegaskan bahwa anak yang beda agama dengan orangtuanya akan terhalang untuk mendapatkan harta kewarisan, perihal ini tidaklah sejalan dengan hukum nasional (KUH Perdata) 2. yang tidak menegaskan bahwa perbedaan agama adalah menjadi penghalang untuk menerima kewarisanan. seorang anak yang lahir dari perkawinan berbeda agama, maka perlu dilakukan upaya perlindungan hukum secara preventif dengan memberikan kepastian hukum secara eksplisit terkait hukum kekeluargaan di Indonesia, tertutama pada UU Perkawinan harus menegaskan secara rinci terkait dengan keabsahan atau tidak perkawinan berbeda agama yang akan berimplikasi terhadap status hak mewaris seseorang. Dan khususnya menjelaskan secara tegas implikasi atau akibat hukum yang timbul dari adanya perkawinan berbeda agama terkhusus implikasi hukum mewaris, yang dimana hukum kewarisan yang sampai saat ini belum juga dilakukan unifikasi di Indonesia.

\section{DAFTAR PUSTAKA}

\section{Buku}

Basuki, Sulistyo, Metode Penelitian. Jakarta: Wedatama Widya Sastra dan Fakultas Ilmu Pengetahuan Budaya Universitas Indonesia, 2006.

Sanjaya, Umar Hari dkk, Hukum Perkawinan Islam di Indonesia, Yogyakarta: Gama Media, 2017.

Soekanto, Soerjono, Pengantar Penelitian Hukum, Jakarta: UI Press, 2008.

\section{Jurnal}

Agustin, Fitria. "Kedudukan Anak dari Perkawinan Berbeda Agama Menurut Hukum Perkawinan Indonesia", Ajudikasi Jurnal Ilmu Hukum Vol. 2, No. 1, (Juni 2018): 44.

Indrayanti, Kadek Wiwik. "Penetapan Dan Pencatatan Perkawinan Berbeda Agama di Indonesia Yang Berkeadilan Dan Berkemanusian”, Jurnal Cakrawala Hukum Vol. 7, No. 2 (Desember 2016): 196.

Milayani, Oktavia. "Kedudukan Hukum Ahli waris Yang Mewaris Dengan Cara Mengganti Atau Ahli waris", Al'Adl Vol. 9, No. 3, (Desember 2017): 406.

Mujib, M.Misbahul. "Memahami Pluralisme Hukum di Tengah Tradisi Unifikasi Hukum: Studi atas Mekanisme Perceraian Adat", Jurnal Supremasi Hukum Vol. 3, No. 1, (Juni 2014): 20.

Munawar, Akhmad. "Sahnya Perkawinan menurut Hukum Positif yang berlaku di Indonesia", Al' Adl-Jurnal Hukum Vol. 7, No. 13, (Juni 2015): 24.

Nasution. Adelina. "Pluralisme Hukum Kewarisan Di Indonesia", Jurnal Al-Qadhâ Vol. 5, No. 1, (Juli 2018): 20.

Nurhasan dan Fitri Yani. "Akibat Hukum Perkawinan di Bawah Tangan terhadap Istri, Anak, dan Harta Kekayaan dalam Perspektif Hukum Islam dan Undang-Undang Nomor 1 Tahun 1974 Tentang Perkawinan”, Jurnal Wajah Hukum Vol.3, No.2, (Oktober 2019): 158

Palandi, Anggreini Carolina. "Analisa Yuridis Perkawinan Berbeda Agama di Indonesia", Lex Privatum Vol. 1, No. 2, (Juni 2013): 197

Rahmat, Pupu Saeful. "Penelitian Kualitatif”, Journal Equilibrium Vol. 5, No. 9, (Juni 2009): 2.

Rokilah. "Implikasi Kewarganegaraan Ganda bagi Warganegara Indonesia", Jurnal Ilmu Hukum "Ajudikasi" Vol. 1, No. 2, (Desember 2017): 132.

Septiandani, Dewi, dkk. "Kontruksi Hukum Perkawinan Berbeda Agama Dalam Perspektif Hukum Islam Dan Hukum Positif Indonesia", Humani Vol.7, No.1, (Januari 2017): 47.

Sudirman, Lu dan Jendy Herlinda Karwur. "Perlindungan Hukum bagi Pasangan yang Melakukan Perkawinan Berbeda Agama di Indonesia", Journal of Judicial Review Vol. 16, No. 2, (Desember 2014): 53.

\section{Peraturan Perundang-Undangan}

Indonesia, Kitab Undang-Undang Hukum Perdata

Indonesia, Undang-Undang Nomor 1 Tahun 1974 tentang Perkawinan

Indonesia, Undang-Undang Nomor 23 Tahun 2002 Tentang Perlindungan Anak

Indonesia, Kompilasi Hukum Islam 